Research article

\title{
THE PERFORMANCE OF SEVEN MOLECULAR METHODS FOR THE DETECTION OF PRRSV
}

\author{
MILIĆEVIĆ Vesna ${ }^{1 *}$, KURELJUŠIĆ Branislav ${ }^{1}$, VELJOVIĆ Ljubiša ${ }^{1}$, \\ VALČIĆ Miroslav², STEVIĆ Nataša ${ }^{2}$, SAVIĆ Božidar ${ }^{1}$, RADOJIČIĆ Sonja ${ }^{2}$ \\ ${ }^{1}$ Institute of Veterinary Medicine of Serbia, Janisa Janulisa 14, Belgrade, Serbia; ${ }^{2}$ Faculty of Veterinary \\ Medicine, University in Belgrade, Bulevar Oslobođenja 18, Belgrade, Serbia
}

(Received 15 November 2019, Accepted 18 February 2020)

\begin{abstract}
Porcine Reproductive and Respiratory Syndrome is a viral disease of swine characterized by reproductive failure of breeding animals and respiratory disorders in all categories. The first PRRS case in Serbia was recorded in 2001 after illegal import of boar semen. PRRS is economically the most important disease due to significant direct and indirect losses. Today, for routine diagnosis of PRRS in infected herds serological methods (ELISA) and molecular methods are used. Although modern diagnostic techniques are very robust, exceptional diversity of the viral strains is often the obstacle for an accurate diagnosis. To estimate the performance of seven different methods for PRRSV genome detection, twenty samples were used. However, none of the methods was able to detect all PRRSV strains. The best sensitivity was obtained by combining two methods. Until today, there is no absolutely accurate test which enables the detection of all circulating strains.
\end{abstract}

Key words: PRRS, RT-PCR, sensitivity, Serbia

\section{INTRODUCTION}

Porcine Reproductive and Respiratory Syndrome (PRRS) is a viral disease of pigs characterized by reproductive disorders in breeding animals and respiratory symptoms in all categories. Retrospective examination revealed that the disease occurred in 1979 in Canada [1]. In Serbia, the first case of PRRS was detected in 2001 after the illegal import of boar semen [2]. PRRS today is considered as the most economically significant pig disease due to its large direct and indirect losses. The causal agent is an RNA virus from the Arteriviridae family, order Nidovirales [3]. There are two genotypes of this virus, genotype 1 formerly known as European and genotype 2 known as North American type [4]. In May 2006, a highly pathogenic strain of PRRS virus, genotype 2, appeared in China, leading to the death of more than 2 million pigs [5]. There are four subtypes within the genotype 1, whereas type 2 strains in Europe are

\footnotetext{
*Corresponding author: e-mail: vesna.milicevic@nivs.rs
} 
genetically homogenous [6]. In Central and Western Europe, only Lelystad virus-like circulates, but in Eastern Europe, all subtypes are present [6]. The PRRS virus genome is not segmented, having a positive polarity and size of about $15 \mathrm{~kb}$ [7]. The genome contains 8 open reading frames (ORF) for encoding structural and non-structural proteins of the virus. A characteristic of the PRRS virus genome, like other RNA viruses, is a high mutation rate of $1.4 \times 10^{-2}$ to $7.7 \pm 2.1 \times 10^{-3}$ nucleotide replacements per year, resulting in a virus divergence of $0.5 \%$ per year [8]. Furthermore, ORF7 is a highly conserved part of the genome at the genotype level, but the similarity between the two genotypes in this part is only $57-59 \%$ [9]. ORF 6 is almost $100 \%$ conserved in genotype 2, while similarity with genotype 1 is $78-81 \%$ [9]. Balka et al [10] suggest that, even though the local evolution is continuously happening, the transboundary movement of infected animals is more important for virus diversity.

The very divergent subtypes of Type 1, furthermore, compromise the accurate diagnosis due to the high rates of false-negative RT-PCR results [6].

PRRS is spread worldwide. The most important epizootiological factor is a persistent infection that allows the virus to be excreted for up to 157 days. PRRS is now considered as the disease with the greatest impact on pig production. Disease control, nowadays, generally involves vaccination. However, the load-close-expose strategy, which consists of closing the herd and exposing the pigs to the virus, is still being in use. In addition to the individual, farm level, there are regional approaches to eradication [11] but also at the national level as has been done in Chile [12]. The diagnosis of PRRS is based on the detection either of the virus itself, its genome or antigen, as well as indirectly by antibody detection, i.e. the immune response to the infection. Due to the significant genetic and antigenic diversity of field isolates, the laboratory diagnosis of PRRS sometimes is very complex [6]. Polymerase chain reaction (PCR) is the most commonly used method for the diagnosis of PRRS, being known for its extremely high analytical sensitivity and specificity. However, diagnostic sensitivity is often not at a satisfactory level. Therefore, the choice of diagnostic methods must be based on the diagnostic characteristics of the assay as determined by examination of local isolates, which was the aim of this paper to demonstrate.

\section{MATERIAL AND METHODS}

Twenty samples of pig tissues, collected during the period 2015-2019 and stored at $-80{ }^{\circ} \mathrm{C}$, were used for investigation, regardless the initial results of PRRS testing, as of suspicion that not all methods had the same performance. Generally, the samples were taken from the animals suspected of PRRS based on clinical symptoms and pathomorphological alterations. The investigation included 13 commercial farms, out of which one was PRRS free. Lung tissue and associated lymph nodes were prepared as $10 \%$ suspensions in phosphate-buffered saline (PBS). After centrifugation at $2000 \mathrm{rpm}$ for 10 minutes, the supernatant was used for RNA isolation, following 
the recommendations of the commercial kit manufacturer (Viral RNA + DNA Preparation kit, Jena Bioscience).

Seven different protocols were used for the PRRS virus genome detection, i.e. 5 for gel-based [13-16] (OneStep RT-PCR Kit, Qiagen) and 2 for real-time RT-PCR [17, 18] (Verso I Step qRT-PCR ROX Kit, Thermo Scientific). Positive and negative controls of both RNA extraction and amplification, as well as non-template control were used for validation purposes. External RNA (VetMAX ${ }^{\mathrm{TM}}$ Xeno $^{\text {TM }}$ Internal Positive Control RNA, Thermofisher Scientific) was added to each sample enabling monitoring of the complete process $\left(V_{\text {VetMAX }}^{\mathrm{TM}}\right.$ Xeno $^{\mathrm{TM}}$ Internal Positive Control - VIC ${ }^{\mathrm{TM}}$ Assay, Thermofisher Scientific). The results of the gel-based RT-PCR were read after electrophoresis at $120 \mathrm{~V}$, for $1 \mathrm{~h}$, in $2 \%$ agarose gel. Samples were considered positive if Ct value was below 35 for real time PCR, or producing the amplified band of expected length for the gel-based PCR.

\section{RESULTS}

By testing 20 tissue samples, the PRRS virus genome was detected in 5 to $70 \%$ of the samples (Table 1) depending on the protocol used.

Table 1. Results of 7 different RT-PCR assays

\begin{tabular}{|c|c|c|c|c|c|c|c|}
\hline $\begin{array}{l}\text { Sample/ } \\
\text { method }\end{array}$ & $\begin{array}{c}\text { A } \\
\text { Gel-based } \\
{[13]}\end{array}$ & $\begin{array}{c}\text { B } \\
\text { Gel-based } \\
{[14]}\end{array}$ & $\begin{array}{c}\text { C } \\
\text { Gel-based } \\
{[15]}\end{array}$ & $\begin{array}{c}\text { D } \\
\text { Gel-based } \\
{[15]}\end{array}$ & $\begin{array}{c}\mathrm{E} \\
\text { Gel-based } \\
{[16]}\end{array}$ & $\begin{array}{c}\text { F } \\
\text { Real time } \\
{[17]}\end{array}$ & $\begin{array}{c}\mathbf{G} \\
\text { Real time } \\
{[18]}\end{array}$ \\
\hline 1 & negative & negative & negative & positive & negative & negative & negative \\
\hline 2 & negative & negative & negative & negative & negative & negative & negative \\
\hline 3 & negative & positive & negative & positive & positive & negative & positive \\
\hline 4 & positive & negative & negative & positive & negative & negative & positive \\
\hline 5 & negative & negative & negative & negative & negative & negative & negative \\
\hline 6 & negative & negative & negative & negative & negative & negative & negative \\
\hline 7 & negative & negative & negative & negative & negative & negative & negative \\
\hline 8 & negative & negative & negative & negative & negative & negative & positive \\
\hline 9 & negative & negative & negative & negative & negative & positive & positive \\
\hline 10 & negative & positive & negative & positive & negative & negative & negative \\
\hline 11 & positive & negative & positive & negative & negative & negative & positive \\
\hline 12 & positive & negative & positive & negative & negative & negative & positive \\
\hline 13 & negative & negative & negative & negative & negative & negative & positive \\
\hline 14 & negative & negative & negative & positive & negative & negative & positive \\
\hline 15 & negative & negative & negative & negative & negative & negative & positive \\
\hline 16 & negative & negative & negative & negative & negative & negative & positive \\
\hline 17 & negative & positive & negative & positive & negative & positive & positive \\
\hline 18 & negative & positive & negative & positive & negative & negative & positive \\
\hline 19 & negative & negative & negative & negative & negative & negative & positive \\
\hline 20 & negative & positive & negative & negative & negative & negative & positive \\
\hline
\end{tabular}


The PRRS virus genome in 4 samples was not detected by any of the applied protocols. In none of the remaining 16 samples, the genome of the virus was detected by all 7 protocols, but at the most with 4 . It has been shown that the most sensitive method [16] was real time RT-PCR intended for the detection of EU strains by amplifying short ORF7 sequence. By protocol G, only 2 strains could not be detected.

\section{DISCUSSION}

Considering the economic significance of the disease, many authors have studied the diagnostic performance of laboratory methods for the diagnosis of PRRS. The common conclusion of the majority is that, before selection for routine diagnostics, it is necessary to evaluate the diagnostic performance of the method using local PRRS virus isolates. The results of this limited study showed that it is often not possible to detect all strains of a virus by one protocol, but it is necessary to combine two or more. By protocol G, 14 positive samples (70\%) were detected, which classifies it as the protocol with the highest diagnostic sensitivity $(87.5 \%)$. However, since the PRRS virus genome was not detected by protocol $\mathrm{E}$ in two samples, by its combining with the D protocol, the diagnostic sensitivity reaches 100\% and ensures that most isolates are detected. Since the genome of the PRRS virus in 4 samples was not detected by any protocol, it was assumed that these samples were negative for the presence of the PRRS virus and that the manifested clinical signs were due to another infection or disease. Analyzing the results concerning the part of the genome that was amplified, it was not possible to identify the part that is most specific for the detection of local isolates from Serbia. Similar results were obtained by comparing gel-based and realtime PCR, where it was not possible to establish a pattern, even though real-time PCR is considered to be an extremely sensitive method.

However, it has been shown that the protocols intended for the detection of only one genotype have a higher sensitivity. To overcome the protocol's imperfections, the sequencing of multiple local isolates and constructing primers and probes for the most conserved part of the genome may be a potential solution. However, with this approach, the risk of false-negative results in the case of imported and emerging strains remains quite high. Sampling time and sample type also influence the PCR results. Blood serum, sperm, blood, and oral fluid are commonly used for active monitoring [19]. The virus genome can be detected in serum, oral fluid, and blood even after 24 to 48 hours after infection [19]. Furthermore, PRRS virus isolates also differ in their degree of replication and excretion. To eliminate these factors that may affect the test results, samples of the same type were used in this study from animals with a clinical presentation at approximately the same stage of infection. Besides, to rule out inhibition of the reaction that may be the cause of the false-negative results, an internal amplification control was used. However, to determine the real reason for the extremely high discrepancy between the protocols used, it is necessary to sequence 
the local isolates and estimate the degree of disagreement between the primer/probe and template sequences [20]. The results of this study, besides showing that not all PRRS isolates can be detected by a single assay, indicate that negative laboratory results do not necessarily mean the absence of the infection, particularly if random sampling was applied. Since the laboratories are expected to employ reliable and accurate methods, continuous protocol updating for molecular detection of the genome of the virus is required. Collaboration between the laboratories and veterinarians, who are expected to indicate any change in clinical manifestation and submit samples for sequencing, allowing the monitoring of the changes in the genome of the virus, and timely adaptation of protocols, are paramount in order to achieve this goal.

\section{Acknowledgements}

This work was supported by the Ministry of Education, Science and Technological Development, Republic of Serbia (grant numbers TR31088, TR 31075).

\section{Authors' contributions}

VM designed the study and drafted the manuscript. BK performed sampling. $\mathrm{LjV}$ carried out the laboratory tests. MV and NS performed the statistical analysis. BS coordinated the work and helped to draft the manuscript. SR conceived the study.

\section{Declaration of conflicting interests}

The author(s) declared no potential conflicts of interest with respect to the research, authorship, and/or publication of this article.

\section{REFERENCES}

1. Dewey C: PRRS in North America, Latin America, and Asia. Vet. Res. 2000, 84-85.

2. Novosel D, Petrović T, Acinger-Rogić Ž, Štukelj M: Epidemiology and status of Porcine Reproductive and Respiratory Syndrome in the Western Balkan region: challenges and prospects. Slov Vet Res 2016, 53: 185-93.

3. Cavanaugh D: Nidovirales a new order comprising Corona-viridae and Arteriviridae. Arch Virol 1997, 142: 629-633.

4. Nelson EA, Christopher-Hennings J, Drew T, Wensvoort G, Collins JE, Benfield DA: Differentiation of U.S. and European isolates of porcine reproductive and respiratory syndrome virus by monoclonal antibodies. J Clin Microbiol 1993, 31: 3184-3189.

5. Tian K, Yu X, Zhao T, Feng Y, Cao Z, Wang C, Hu Y, Chen X, Hu D, Tian X, Liu D, Zhang S, Deng X, Ding Y, Yang L, Zhang Y, Xiao H, Qiao M, Wang B, Hou L, Wang X, Yang X, Kang L, Sun M, Jin P, Wang S, Kitamura Y, Yan J, Gao GF: Emergence of fatal PRRSV 
variants: unparalleled outbreaks of atypical PRRS in China and molecular dissection of the unique hallmark. PLoS One 2007, 2:e526.

6. Stadejek T, Stankevicius A, Murtaugh MP, Oleksiewicz MB: Molecular evolution of PRRSV in Europe: current state of play. Vet. Microbiol. 2013, 165(1-2):21-8. doi: 10.1016/j. vetmic.2013.02.029.

7. Renson P, Touzain F, Lebret A, Le Dimna M, Quenault H, Normand V, Claude JB, Pez F, Rose N, Blanchard Y, Bourry O: Complete Genome Sequence of a Recombinant Porcine Reproductive and Respiratory Syndrome Virus Strain from Two Genotype 1 Modified Live Virus Vaccine Strains. Genome Announc 2017, 5(22): e00454-17.

8. https : //www.prrs.com/en/prrs/virus

9. Meng XJ, Paul PS, Halbur PG, Lum MA: Phylogenetic analyses of the putative M (ORF 6) and $\mathrm{N}$ (ORF 7) genes of porcine reproductive and respiratory syndrome virus (PRRSV): implication for the existence of two genotypes of PRRSV in the U.S.A. and Europe. Arch Virol 1995, 40(4):745-55.

10. Balka G, Podgórska K, Brar MS et al: Genetic diversity of PRRSV 1 in Central Eastern Europe in 1994-2014: origin and evolution of the virus in the region. Sci Rep 2018, 8 (7811) https://doi.org/10.1038/s41598-018-26036-w

11. Corzo CA, Mondaca E, Wayne S, Torremorell M, Dee S, Davies P, Morrison RB: Control and elimination of porcine reproductive and respiratory syndrome virus. Virus Res 2010, 154: 185-192.

12. Neira V, Brito B, Mena J, Culhane M, Apel MI, Max V, Perez P, Moreno V, Mathieu C, Johow M, Badia C, Torremorell M, Medina R, Ortega R: Epidemiological investigations of the introduction of porcine reproductive and respiratory syndrome virus in Chile, 20132015. PLoS One 2017, 12(7):e0181569.

13. Donadeu M, Arias M, Gomez-Tejedor C, Agüero M, Romero L, Christianson TW, SánchezVizcaíno J: Using polymerase chain reaction to obtain PRRSV-free piglets from endemically infected herds. Swine Health Prod. 1999, 7(6): 255-261.

14. Gilbert SA, Larochelle R, Magar R, Cho HJ, Deregt D: Typing of porcine reproductive and respiratory syndrome viruses by a multiplex PCR assay. Journal of clinical microbiology 1997, 35(1), 264-267.

15. Stadejek T, Stankevicius A, Storgaard T, Oleksiewicz MB, Belak S, Drew TW, Pejsak Z: Identification of radically different variants of porcine reproductive and respiratory syndrome virus in Eastern Europe: towards a common ancestor for European and American viruses. J Gen Virol 2002, 83:1861-1873.

16. Madsen KG, Hansen CM, Madsen ES, Strandbygaard B, Bøtner A, Sørensen KJ: Sequence analysis of porcine reproductive and respiratory syndrome virus of the American type collected from Danish swine herds. Arch Virol. 1998, 143(9):1683-700.

17. Kleiboeker SB, Schommer SK, Lee SM, Watkins S, Chittick W, Polson D: Simultaneous detection of North American and European porcine reproductive and respiratory syndrome virus using real-time quantitative reverse transcriptase-PCR. J Vet Diagn Invest. 2005, 17:165-170.

18. Opriessnig T, McKeown NE, Harmon KL, Meng XJ, Halbur PG: Porcine Circovirus Type 2 Infection Decreases the Efficacy of a Modified Live Porcine Reproductive and Respiratory Syndrome Virus Vaccine. Clinical and Vaccine Immunology 2006, 13(8):923-929.

19. Gerber PF, O’Neill K, Owolodun O, Wang C, Harmon K, Zhang J, Halbur P G, Zhou L, Meng X-J, Opriessnig T: Comparison of Commercial Real-Time Reverse TranscriptionPCR Assays for Reliable, Early, and Rapid Detection of Heterologous Strains of Porcine 
Reproductive and Respiratory Syndrome Virus in Experimentally Infected or Noninfected Boars by Use of Different Sample Types, J Clin Microbiol 2013, 51(2): 547-556.

20. Toplak I, Rihtarič D, Hostnik P, Grom J, Stukelj M, Valenčak Z: Identification of a genetically diverse sequence of porcine reproductive and respiratory syndrome virus in Slovenia and the impact on the sensitivity of four molecular tests. J Virol Methods 2012, 179(1):51-6.

\title{
KARAKTERISTIKE SEDAM RAZLIČITIH MOLEKULARNIH METODA ZA DETEKCIJU VIRUSA PRRS-A
}

\author{
MILIĆEVIĆ Vesna, KURELJUŠIĆ Branislav, VELJOVIĆ Ljubiša, \\ VALČIĆ Miroslav, STEVIĆ Nataša, SAVIĆ Božidar, RADOJIČIĆ Sonja
}

Reproduktivni i respiratorni sindom svinja je virusno oboljenje svinja koje se karakteriše reproduktivnim poremećajima kod priplodnih životinja i respiratornim simptomima kod svih kategorija. U Srbiji je prvi slučaj PRRS-a otkriven 2001. godine nakon ilegalnog uvoza semena nerastova. PRRS se danas smatra ekonomski najznačajnijom bolešću svinja usled velikih direktnih i indirektnih gubitaka. Danas se za rutinsku dijagnostiku PRRS-a u zaraženim stadima koriste serološke metode (ELISA) i molekularne metode. Iako su savremene dijagnostičke tehnike veoma moćne, izuzetna raznolikost sojeva ovog virusa je često prepreka ka postavljanju pouzdane dijagnoze. U cilju utvrđivanja performansi sedam različitih metoda za detekciju PRRS virusa, koristili smo dvadeset uzoraka. Međutim, nijedna od metoda nije bila u stanju da otkrije sve PRRSV sojeve. Najbolja osetljivost je dobijena kombinovanjem dve metode. Treba naglasiti da ne postoji potpuno pouzdan test kojim se mogu dokazati svi sojevi virusa zbog čega je često potrebno kombinovati više testova ili metoda. 